Article

\title{
Sediment Characteristics of Beachrock: A Baseline Investigation Based on Microbial Induced Carbonate Precipitation at Krakal-Sadranan Beach, Yogyakarta, Indonesia
}

\author{
Lutfian Rusdi Daryono ${ }^{1, *}{ }^{\circledR}$, Kazunori Nakashima ${ }^{2}$, Satoru Kawasaki $\left.{ }^{2}{ }^{(}\right)$, \\ Anastasia Dewi Titisari ${ }^{3}$ and Didit Hadi Barianto ${ }^{3}$ \\ 1 Laboratory of Biotechnology for Resource Engineering, Division of Sustainable Resources Engineering, \\ Graduate School of Sustainable Resources Engineering, Hokkaido University, Hokkaido 060-8628, Japan \\ 2 Laboratory of Biotechnology for Resource Engineering, Division of Sustainable Resources Engineering, \\ Faculty of Engineering, Hokkaido University, Hokkaido 060-8628, Japan; \\ nakashima@geo-er.eng.hokudai.ac.jp (K.N.); kawasaki@geo-er.eng.hokudai.ac.jp (S.K.) \\ 3 Department of Geological Engineering, Faculty of Engineering, Universitas Gadjah Mada, Yogyakarta 55281, \\ Indonesia; adtitisari@gmail.com (A.D.T.); didit_geologi@ugm.ac.id (D.H.B.) \\ * Correspondence: luthfian.daryono@gmail.com; Tel.: +81-11-706-6325
}

Received: 27 November 2019; Accepted: 6 January 2020; Published: 10 January 2020

check for updates

Featured Application: Biotic control of carbonate sedimentation characteristics found in beachrock was proven to provide a natural barrier with potential as a natural countermeasure to coastal hazards. The ureolytic bacteria that induce carbonate biomineralization of beachrock were investigated to identify the sedimentary mechanism. This study found that a bioengineering approach using bacterial biomineralization mimicking beachrock could be implemented to mitigate marine erosion. However, the results presented in this paper represent a base-line study and more thorough investigations, including scaling up, should be conducted in the future.

\begin{abstract}
Isolation of ureolytic bacteria and geochemical analysis of beachrock from Krakal-Sadranan Beach (Yogyakarta, Indonesia) were conducted to determine natural sedimentary characteristics of the beachrock. The beachrock was also examined to determine the depositional conditions and distribution of rare earth elements. An increased concentration of total rare earth elements, both heavy rare earth elements (terbium, dysprosium, yttrium, holmium, erbium, thulium, ytterbium, and lutetium) and light rare earth elements (lanthanum, cesium, praseodymium, neodymium, samarium, europium, and gadolinium) signals that the beachrock deposition process happened under oxidative environmental conditions. This study proposes the novel use of ureolytic bacteria in a depositional environment for carbonate control of a sedimentary process for the development of artificial rock to mitigate coastal erosion. The resulting bacterial strains are highly homologous to the 16S rDNA nucleotide sequence of the species Oceanobacillus profundus, Vibrio maritimus, and Pseudoalteromonas tetradonis.
\end{abstract}

Keywords: ureolytic bacteria; isolation; diagenetic process; beachrock; microbial

\section{Introduction}

The precipitation of solid matter from dissolved substances in seawater occurs either abiotically (governed by inorganic thermodynamics and reaction kinetics) or biotically (as a metabolic consequence 
of living organisms). This process is primarily controlled by the biochemistry of organisms including algae, foraminifera, cyanobacteria, and corals but is also influenced by the marine conditions where they live. Beachrock (Figure S1) is a carbonate sedimentary product with an anchoring effect for dynamic islands and provides protection from erosion [1-3]. The sedimentary characteristics of beachrock have been investigated; however, many things about its origin and properties remain unknown or are subject to debate. Outcrops of beachrock are valuable records of the past climate of the low-lying reef islands generally found in tropical and subtropical areas with generally warm seawater [4-6]. Carbonate cement occurs as precipitation from interstitial seawater and or seawater waves $[7,8]$, coastal aquifers featuring the mixture of saltwater and freshwater [9], or at sea level due to $\mathrm{CO}_{2}$ degassing [1], with biological activity as an additional agent [10]. Indonesia's coastline is among the largest of any country, and Indonesian beaches face unique issues. Compounding effects and conflicts arise in a complex manner with emergent and cross-scaled impacts, including manifold potential change drivers (e.g., climate change, urbanization, tourism development, and marine resource exploitation) [11-15].

Beachrock in some areas has not yet been subjected to study. The beachrock found on Krakal-Sadranan Beach is distributed parallel to the coastline, with a coverage of around $10-30 \mathrm{~m}^{2}$. The research area is located on a coastline that extends along the south of Java Island (the South Coast). It is included in the Wonosari-Punung Formation according to the regional geological map [16-20] (Supplementary Materials S1-S3) of the Surakarta-Giritontro sheet [20]. The authors chose this particular location due to the unexplored sedimentary and diagenesis beachrock in the area around Krakal-Sadranan Beach, as well as the lack of records on beachrock occurrence. The aim of this study was to identify the ureolytic bacteria that induced the natural beachrock. This study serves as an initial exploration of beachrock sedimentary processes in the area and as a basis for future studies. These might include studies of the rocks' age based on carbon dating and the development of artificial beachrock using microbially induced carbonate precipitation (MICP) to resolve coastal erosion or other issues. As an initial step towards achieving this goal, native indigenous ureolytic strains were isolated from Indonesian beachrock and beach sand and their bioaugmentation potential. Upon receiving more successful results for MICP treatment using a marine ureolytic bacterium for the desired engineering application, further studies were carried out to (i) isolate a local strain of ureolytic bacteria from natural beachrock, (ii) optimize the growth and enzymatic activity of the isolated strain, and (iii) explore the chemical compounds in the natural beachrock cementation material in nearshore environments as an alternative technique for sand stabilization.

\section{Materials and Methods}

\subsection{Field Investigation}

Fieldwork was carried out by extracting a horizontal sample at several locations along the coastline in the study area (less than or equal to $1 \mathrm{~m}$ near the surface) from June 2017 to December 2018. Each operation was conducted separately. At each location that was sampled, 19 samples were taken based on their horizontal and vertical positions. Sampling was conducted based on the presence of beachrock along the trench. Then, the lithostratigraphy of the samples was identified and beachrock samples were isolated. The field investigation was conducted in the Krakal-Sadranan Beach area, (Wonosari, Yogyakarta, Indonesia) (Figure S2, Supplementary Material), within which the regional geology control and sedimentary processes were correlated [18]. The study area was located around $07^{\circ} 08^{\prime} 42,55^{\prime \prime}$ and $110^{\circ} 26^{\prime} 11,31^{\prime \prime}$ in Indonesia. The azimuth of the beachrock deposits, in general, was at $\mathrm{N} 334^{\circ} \mathrm{E}$ (crossing the shoreline beach) or $\mathrm{N} 164^{\circ} \mathrm{E}$ (parallel with the shoreline). 


\subsection{Laboratory Analysis}

\subsubsection{Petrographic Studies}

In this study, beachrock types were grouped according to Folk's classification of carbonate rocks (Folk, 1962, as cited in [21]) using five properties: grain size, chemically precipitated cements, textural maturity, miscellaneous transported constituents, and clan designation. Folk's fivefold name must be in the following format: (Grain size): (chemically precipitated cements) (textural maturity) (miscellaneous transported constituents) (clan designation). Samples of beachrock that were brittle and poorly sorted were easy to break into pieces. Resin was added to such samples to solidify them, and they were cut to make thin sections for microscope slides. The collected samples were then examined in the laboratory using an optical petrographic microscope equipped for polarized light microscopy. The petrographic analysis was carried out at the Optical Geology Laboratory to assess the biostratigraphy of the samples.

2.2.2. Inductively Coupled Plasma-Atomic Emission Spectroscopy and Mass Spectrometry (ICP-AES and MS)

Each prepared beachrock sample $(10 \mathrm{~g})$ was added to lithium metaborate/lithium tetraborate flux, well mixed, and fused in a furnace at $1000{ }^{\circ} \mathrm{C}$. Then, each sample was cooled and dissolved in 100 $\mathrm{mL}$ of $4 \%$ nitric acid and $2 \%$ hydrochloric acid for preparation and reduce of organic compound of samples. This solution was then analyzed using ICP-AES in the laboratory of ALS Canada Ltd. (North Vancouver, Canada). Major and trace elements were analyzed by ALS Canada Ltd. (North Vancouver, BC) using the ICP-AES and ICP-MS (method code ME-MS81L, iCAP 6000 Thermo Fischer Scientific) methods after aqua regia digestion (ARD) for combined whole rock analysis, trace elements by fusion and aqua regia digestion for the volatile trace elements, carbon and sulfur for combustion analysis, and several detection limit options for base metals. Four certified reference materials, ME-ICP06, OA-GRA05, ME-MS81, and TOT-ICP06, were measured using the same procedure as the samples for data calibration [18]. The loss on ignition (LOI) was determined using the gravimetric method. Each prepared beachrock sample $(10 \mathrm{~g})$ was placed in an oven at $1000{ }^{\circ} \mathrm{C}$ for one hour, cooled, and then weighed. The resulting material was then cooled and dissolved in an acid mixture containing nitric, hydrochloric, and hydrofluoric acids. Beachrock sample consists of $90 \%$ carbonate compound, therefore it was sensitive to the acid solution during the chromatography analysis. The normalization values for plotting the trace element concentration of the limestone samples are from the Average Phanerozoic Limestone [19], while Post-Archean Australian Shale (PAAS) normalization [22] was used for plotting major oxide and rare earth element (REE) concentrations in the samples [23,24].

\subsubsection{Algae Taxonomy}

Macroalgae can be divided into three divisions based on their primary pigment color: Chlorophyta (green algae), Rhodophyta (red algae), and Phaeophyta (brown algae) [25]. Green algae are abundant in warm (trophic) waters and at least 12 genera of green algae were recorded [26]. Algae were found in the intertidal zone of Krakal Beach and samples were collected by purposive random sampling. Each sample was taken completely from the substrate for identification. Samples taken by purposive random sampling from each quadrat plot were stored in Ziplock plastic bags. Then, samples were cleaned and photographed on millimeter block paper for identification. The identification results showed the seaweed diversity based on identification using the FAO Species Identification Guide for Fishery Purpose [27].

\subsubsection{Isolation and Identification of a Suitable Urease Active Bacterium}

We hypothesized that there was likely to be a close biomineralization relationship between algae and other agents in microbial mats. Moreover, to identify the microbial activity, a $5.0 \mathrm{~g}$ sample of beachrock was mixed with $10 \mathrm{~mL}$ of autoclaved artificial seawater (Aquamarine, Yashima Drug Company, Osaka, Japan; Table 1), then diluted $10^{1}-10^{4}$ times with artificial seawater. Next, $10 \mu \mathrm{L}$ of 
each dilution was added to ZoBell2216E agar medium (for marine bacteria, $\mathrm{pH}$ 7.7) and $\mathrm{NH}_{4}$-YE agar medium for inland bacteria $\left(20 \mathrm{~g} / \mathrm{L}\right.$ yeast extract; $10 \mathrm{~g} / \mathrm{L}$ di-ammonium sulfate $\left(\mathrm{NH}_{4}\right)_{2} \mathrm{SO}_{4} ; 0.13 \mathrm{M}$ Tris buffer for $\mathrm{pH}$ 8.0), and $20 \mathrm{~g} / \mathrm{L}$ agar amended to isolate micro bacteria resistant strains as target study of this research. To avoid contamination, every step of the investigation was conducted inside a clean bench. After incubation at $35^{\circ} \mathrm{C}$ for $3 \mathrm{~d}$, about $\sim 53$ colonies from each location were isolated from the plates. A urease activity test was then conducted on the colonies to identify ureolytic bacteria. Each selected colony (diameter: $2-3 \mathrm{~mm})$ was mixed with $20 \mathrm{~mL}$ of solution $(20 \mathrm{~mL} / \mathrm{L}$ cresol red solution, $0.4 \mathrm{~g} / \mathrm{L}$ cresol red with distilled water, and $25 \mathrm{~g} / \mathrm{L} \mathrm{CO}\left(\mathrm{NH}_{2}\right)_{2}$ with distilled water) in a $20 \mathrm{~mL}$ bottle. The samples were then sealed, mixed by shaking, and then incubated at $45^{\circ} \mathrm{C}$ for $2 \mathrm{~h}$. To determine whether or not the colonies have urease activity, we observed the color of the solution after $2 \mathrm{~h}$. There was a change in the cresol red, from yellow to purple as $\mathrm{pH}$ increased from 7.2 to 8.8.

Table 1. Composition of artificial seawater (Aquamarine, Japan).

\begin{tabular}{cc}
\hline Reagent & $(\mathbf{g} / \mathbf{2 0 ~ L )}$ \\
\hline $\mathrm{MgCl}_{2} \cdot 6 \mathrm{H}_{2} \mathrm{O}$ & 222.23 \\
$\mathrm{CaCl}_{2} \cdot 2 \mathrm{H}_{2} \mathrm{O}$ & 30.7 \\
$\mathrm{SrCl}_{2} \cdot 6 \mathrm{H}_{2} \mathrm{O}$ & 0.85 \\
$\mathrm{SrCl}_{2} \cdot 6 \mathrm{H}_{2} \mathrm{O}$ & 13.89 \\
$\mathrm{KCl}$ & 4.02 \\
$\mathrm{NaHCO}_{3}$ & 2.01 \\
$\mathrm{KBr}$ & 0.54 \\
$\mathrm{H}_{3} \mathrm{BO}$ & 0.06 \\
$\mathrm{NaF}_{3}$ & 490.68 \\
$\mathrm{NaCl}$ & 81.88 \\
$\mathrm{Na}_{2} \mathrm{SO}_{4}$ & 0.06 \\
\hline
\end{tabular}

Gene amplification (16S rRNA) and sequencing was carried out for selected ureolytic isolates. The analysis of the DNA sequences was performed using the DB-BA 12.0 and International Nucleotide Sequence Database created by the Techno Suruga Laboratory, Shizuoka, Japan. The ureolytic bacteria isolated were identified using $16 \mathrm{~S}$ rRNA sequence analysis. DNA extracts were amplified using two sets of primers targeting the region-specific $16 \mathrm{~S}$ rRNA sequences for almost all bacterial $16 \mathrm{~S}$ sequences: the F9 (5'-GAGTTTGATCCTGGCTCAG-3') and R1451 (5'-AAGGAGGTGATCCAGCC-3') primers. The PCR amplification cycle consisted of an initial denaturation step lasting $5 \mathrm{~min}$ at $94^{\circ} \mathrm{C}$, followed by 25 cycles lasting $1 \mathrm{~min}$ at $94^{\circ} \mathrm{C}, 2 \mathrm{~min}$ at $60^{\circ} \mathrm{C}, 1 \mathrm{~min}$ at $72^{\circ} \mathrm{C}$, and a final extension step of $30 \mathrm{~min}$ at $72{ }^{\circ} \mathrm{C}$. The amplicons were separated through gel electrophoresis, and the resulting DNA bands were extracted and purified using the FastGene ${ }^{\mathrm{TM}}$ PCR extraction kit according to manufacturer instructions (Nippon Genetics Co., Ltd., Tokyo, Japan). The extracted DNA was sent to the Eurofins Genomics Laboratory (Eurofins Genomics, Tokyo, Japan) for sequencing. Subsequent phylogenetic analysis was conducted by TechnoSuruga Laboratory (TechnoSuruga Laboratory Company Ltd., Tokyo, Japan). The latter used the BLAST algorithm to find related sequences in the GeneBank Database, DNA Data Bank of Japan, and the European Molecular Biology Laboratory. PCR sequencing was conducted to identify the species of ureolytic bacteria isolated from the sites at Krakal-Sadranan.

\subsubsection{Cultivation of Bacteria and Assessing the Potential for Microbial Induced Carbonate Precipitation}

Standard media (Zobell 2216E for marine bacteria and $\mathrm{NH}_{4}$-YE medium for land bacteria) were used for culturing under sterile aerobic conditions. Cells were precultured separately in $5 \mathrm{~mL}$ of each medium at $37^{\circ} \mathrm{C}$ and $160 \mathrm{rpm}$ for $24 \mathrm{~h}$. One milliliter of the preculture was inoculated with $100 \mathrm{~mL}$ of the fresh medium and incubated under the same conditions. The microbial cell growth of the isolates was determined based on optical density at a wavelength of $600 \mathrm{~nm}\left(\mathrm{OD}_{600}\right)$ using a UV-vis spectrophotometer (V-730, JASCO Corporation, Tokyo, Japan). Representative specimens were sampled at regular intervals of $24 \mathrm{~h}$. Microbially induced calcium carbonate precipitation tests 
were conducted in $10 \mathrm{~mL}$ tubes to evaluate the feasibility of using isolated bacterial strains. Calcium chloride $\left(\mathrm{CaCl}_{2}\right)$ reagent was chosen as the calcium source, and $1 \mathrm{~mL}$ from equimolar concentrations $(0.5 \mathrm{~mol} / \mathrm{L}(\mathrm{M}))$ of $\mathrm{CaCl}_{2}$ and urea solutions were used. One milliliter of the bacteria culture was added to the tube, and the total volume was adjusted to $10 \mathrm{~mL}$ using distilled water. Samples were then placed in a shaking incubator at $37^{\circ} \mathrm{C}$ and shaken at $160 \mathrm{rpm}$ for $48 \mathrm{~h}$. Finally, the reaction mixtures were centrifuged, precipitates were collected, and the amount of precipitate formed by each isolate were gravimetrically compared. Based on the results, a single isolate was selected as the most suitable for further analysis.

\subsubsection{Syringe Biocementation Test}

The local beach sand used in the experiments was uniformly graded with a mean particle size of $0.9 \mathrm{~mm}$ for coarse sand and $0.6 \mathrm{~mm}$ for fine sand (Figure 1). The sand was sterilized, and hand packed into a $50-\mathrm{mL}$ syringe (mean diameter, $\mathrm{D}_{50}=3 \mathrm{~cm}$ and height, $\mathrm{h}=10 \mathrm{~cm}$ ). This was followed by gentle injection of bacteria and solidification solution, as illustrated in Figure S3 (Supplementary Material) . The bacterial suspension was injected first and allowed to stand in the column for $2 \mathrm{~h}$; thereafter, solidification solution was injected. This was repeated every $24 \mathrm{~h}$ for a period of $14 \mathrm{~d}$. In addition, two sets of biocementation experiments were conducted using conditions designed to mimic the possible conditions for in situ injection of treatment solutions. The first set of experiments involved using coarse local sand of which the main content was skeletal shell carbonate. The other set of experiments involved the use of iron-silica fine sand (fluvio-volcanic sand) of the Young Merapi deposit. In both injection conditions, $20 \mathrm{~mL}$ of cementation solution was left above the surface of the sand to mimic saturated conditions, and this procedure was called the immersed method. Control tests were also conducted following the same procedures but without the addition of bacterial cells. First, $100 \mathrm{~mL}$ ZoBell 2216E medium solution (polypeptone $5.0 \mathrm{~g} / \mathrm{L}$, yeast extract $1.0 \mathrm{~g} / \mathrm{L}$, and FePO4 $0.1 \mathrm{~g} / \mathrm{L}$ with artificial seawater) was inoculated with $0.1 \mathrm{~g}$ of the ureolytic bacterium isolated by the above test, then incubated at $37^{\circ} \mathrm{C}$ with gentle shaking at $160 \mathrm{rpm}$ for $3 \mathrm{~d}$. Next, $80 \mathrm{~g}$ of coral sand and silica sand collected from the Yogyakarta south coast was dried at $110^{\circ} \mathrm{C}$ for $2 \mathrm{~d}$ and then placed in a $50 \mathrm{~mL}$ syringe (diameter $3 \mathrm{~cm}$ ). Subsequently, $16 \mathrm{~mL}$ (more than the estimated $14 \mathrm{~mL}$ initial pore volume in the sample) of bacterial culture and $20 \mathrm{~mL}$ of the cementation solution (Table 2) were sequentially added to the syringe and drained, leaving about $2 \mathrm{~mL}$ of solution above the surface of the sand (saturated condition). This solidification test was conducted for 14 cementation injections in $14 \mathrm{~d}$.

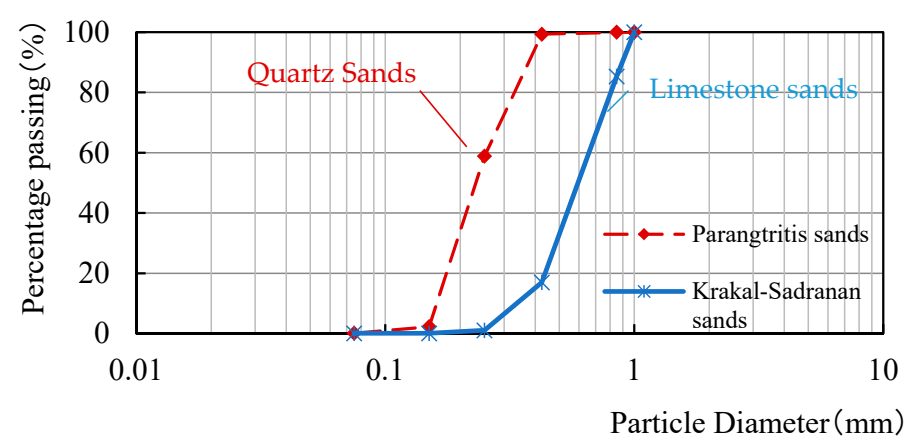

Figure 1. Particle size distribution of local beach sand from Yogyakarta south coast, Indonesia.

Table 2. Standard composition of cementation solution $0.5 \mathrm{M}$ (solvent in artificial seawater).

\begin{tabular}{cc}
\hline Reagent & Content $(\mathrm{g} / \mathrm{L})$ \\
\hline Nutrient broth & 3.0 \\
$\mathrm{NH}_{4} \mathrm{Cl}$ & 10.0 \\
$\mathrm{NaHCO}$ & 2.12 \\
Urea, $\mathrm{Co}\left(\mathrm{NH}_{2}\right)_{2}$ & 18.02 \\
$\mathrm{CaCl}_{2}$ & 33.3 \\
\hline
\end{tabular}




\section{Results}

\subsection{Stratigraphy of Krakal-Sadranan Beachrock}

The studied samples were categorized as non-beachrock, unconsolidated beachrock and well-consolidated beachrock, based on their skeletal, mineral and rock fragments (Figure 2B). It was observed that most of the samples obtained at sampling/stratigraphic columns (e.g., ABX1) were limestone sand with sparse biomicrite cement. Sample X1, for example, contains limestone fragments $(30 \%)$, fossil shell fragments (35\%) and limestone sand (35\%). Figure 2 is shown the degree of cementation based on stratigraphy analysis. Refer the supplementary material (Figures S5 and S6) for further information about trenches CD and EF. Moreover, the other classification is sparse biomicrite beachrock consist of whitish-yellow color, $4 \mathrm{~mm}$ fragment size and base mass $<1 \mathrm{~mm}$, subangular grain shape, open container, massive structure, about $20-25 \mathrm{~cm}$ in thickness with up to $90 \%$ of rocks fragment, minerals insisting $5 \%$, and less then $2 \%$ of skeletal fragments form, respectively.
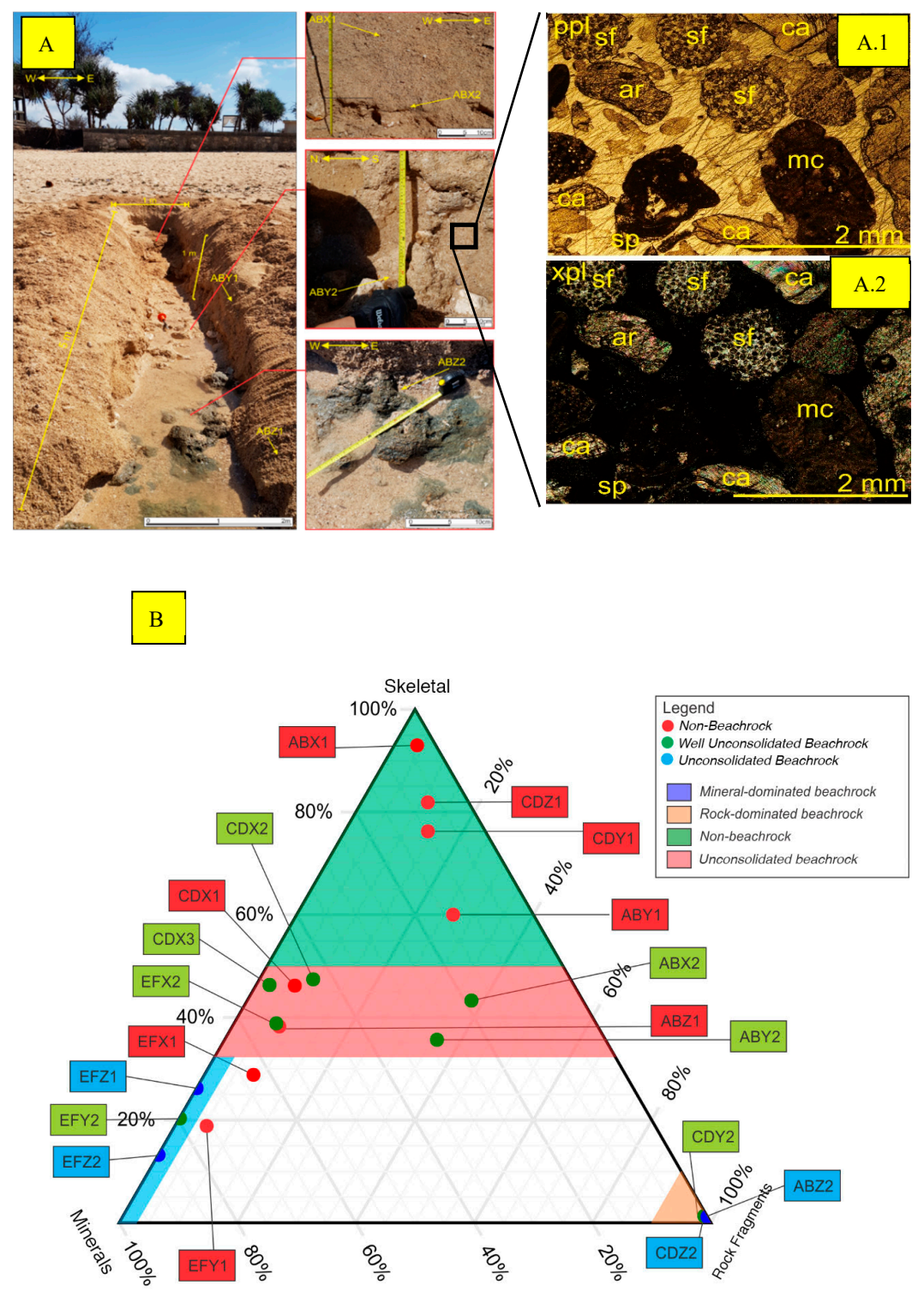

Figure 2. Stratigraphic of the Trench AB: (A) Petrographic on cross polarized nicol (XPL, A1) and plane polarized nicol (PPL, A2) with sf (skeletal fragment), mc (micrite), sp (sparite), ca (calcite) and ar (aragonite); (B) Degree of cementation based on composition of beachrock. 


\subsection{ICP-AES and ICP-MS Analysis}

Geochemically, enrichment of some major oxide concentrations such as calcium oxide $(\mathrm{CaO})$ and magnesium oxide (MgO) shown in Table S1 (Supplementary Material) indicates that most minerals were beachrock. Furthermore, the increase of $\mathrm{MnO}$ concentration is proportional to beachrock changing into calcite dominant. The increasing $\mathrm{MnO}$ were found in samples that evaporated more intensely than beachrock in the swash zone. The major oxide data from Table S1 shows that beachrock contain $\mathrm{CaO}$ concentration ranging from $43.7-49.9$ wt. $\%, \mathrm{SiO}_{2} 0.9-3.07$ wt. $\%, \mathrm{Al}_{2} \mathrm{O}_{3} 0.26-2.38$ wt. $\%, \mathrm{Fe}_{2} \mathrm{O}_{3}$ 0.26-1.25 wt.\%, $\mathrm{TiO}_{2} 0.01-0.09 \mathrm{wt} . \%$, and $\mathrm{MnO} 0.01-0.06 \mathrm{wt} . \%$. Loss on Ignition (LOI) in the samples of this study ranged from $41.80-44.80 \%$ (wt. $\%$ ) of $\mathrm{CO}_{2}$ concentration.

$\mathrm{CaO}, \mathrm{MgO}$ and $\mathrm{LOI}$ (loss on ignition) are the major components identified by chemical analysis (refer supplement S7), which shows a very good aggreement with the major components of limestone-sand samples [28-30]. It should be noted that minor presence of $\mathrm{Mg}$ is in the carbonate phase (i.e., magnesian calcite, or mixture of calcite and dolomite). $\mathrm{MnO}$ content was also identified in samples, that underwent more intense evaporation than beachrock in the swash zone. Elevated abundances of $\mathrm{Al} 2 \mathrm{O} 3, \mathrm{TiO} 2$ and $\mathrm{Zr}$ indicate increased amount of detrital component. A gradual decrease of $\mathrm{CaO}$ concentration is also observed from beachrock in the swash zone to carbonate sands in dryland areas. This might be related with the decreased deposition of nutrients from the sea [31,32]

The rare earth element (REE) patterns of the various beachrock samples vary in a consistant manner (Figure 3). All the samples exhibit negative cerium and positive yttrium anomalies. This is also in concordance with precipitation from sea-water [33-35].

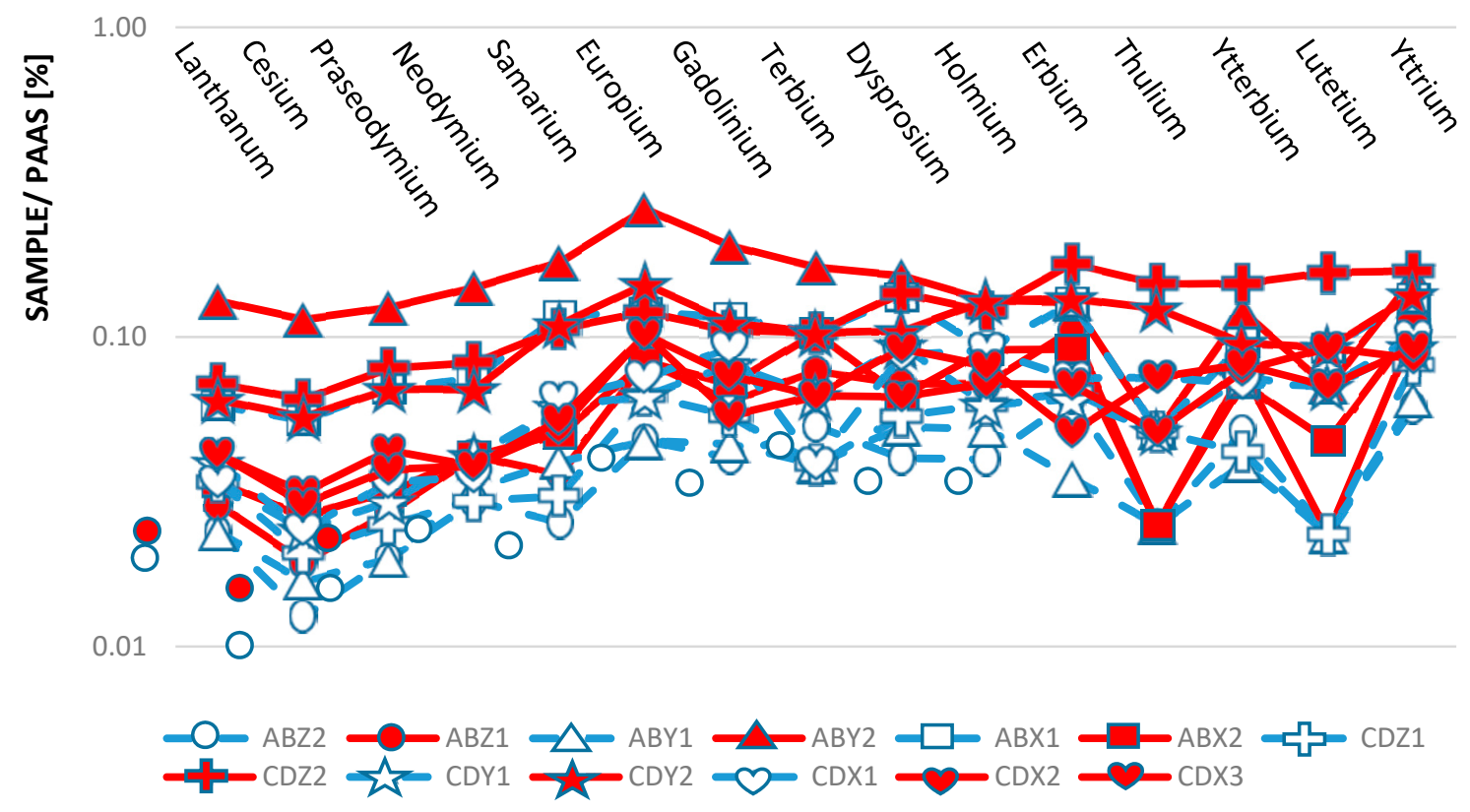

Figure 3. Rare elements analysis diagram of beachrock based on shale normalization.

\subsection{Biodiversity Observations}

\subsubsection{Algae Taxonomy}

A total of six marine plant species were recorded across the six samples taken from the Krakal-Sadranan Beach. The recorded algal species included one species of green algae, one species of brown algae, and four species of red algae (Table 3). At macroscale, algae could be home to macrobenthos, microbenthos, and microorganisms surrounding beachrock or coral reef $[36,37]$. In the end, those six species of algae were identified as being predominant in the Krakal-Sadranan Beach study area and of close proximity to the beachrock [38]. 
Table 3. Algae species taxonomy surrounded beachrock.

\begin{tabular}{|c|c|c|c|c|c|c|}
\hline \multirow{2}{*}{ No. } & \multicolumn{6}{|c|}{ Location $07^{\circ} 08^{\prime} 42,55^{\prime \prime}-110^{\circ} 26^{\prime} 11,31^{\prime \prime}$} \\
\hline & Division & Class & Ordo & Familia & Genus & Species Name \\
\hline 1. & \multirow{4}{*}{ Rhodophyta } & \multirow{2}{*}{ Florideophyceae } & Ceramiales & Rhodomelaceae & Laurencia & $\begin{array}{l}\text { Laurencia pappilosa } \\
\text { (C. Agardh) Greville }\end{array}$ \\
\hline 2. & & & Gelidiales & Gelidiaceae & Gelidium & $\begin{array}{l}\text { Gelidium corneum } \\
\text { (Hudson) Lam. }\end{array}$ \\
\hline 3. & & \multirow[b]{2}{*}{ Rhodophyceae } & Gigartinales & Gigartinaceae & Gigartina & Gigartina sp \\
\hline 4. & & & Rhodymeniales & Rhodymeniceae & Rhodymenia & $\begin{array}{l}\text { Rhodymenia } \\
\text { pseudopalmata } \\
\text { (Lam.) P.Silva }\end{array}$ \\
\hline 5. & Phaeophyta & Phaeophyceae & Fucales & Sargassaceae & Sargassum & $\begin{array}{c}\text { Sargassum } \\
\text { duplicatum Bory }\end{array}$ \\
\hline 6. & Chlorophyta & Chlorophyceae & Ulotrichales & Ulvaceae & Ulva & Ulva Lactuca L. \\
\hline
\end{tabular}

\subsubsection{Isolation of Indigenous Ureolytic Bacteria}

The isolation of indigenous ureolytic bacteria analysis was carried out in the Biotechnology Laboratory UGM. The beachrock samples by the seashore and other outcrops found in Krakal-Sadranan were placed in sterile tubes and diluted 10-104 times with artificial seawater. Afterwards, $10 \mu \mathrm{L}$ of each dilution was added to ZoBell2216E agar medium for marine bacteria and being incubated at $37^{\circ} \mathrm{C}$ for 3 days. The cells cultured were ureolytic bacteria in ZoBell2216E and $\mathrm{NH}_{4}-\mathrm{YE}$ media, which also contained 5.0/L hipolypeptone (Nihon Seiyaku Co., Ltd., Tokyo, Japan), 1.0 g/L FePO (Junsei Chemical Co., Ltd., Tokyo, Japan), and $1.0 \mathrm{~g} / \mathrm{L}$ yeast extract (BD Bioscience Adv., Bioprocessing, Miami, Florida, USA). These were prepared with artificial seawater with $\mathrm{pH}$ 7.6-7.8, adjusted using $1 \mathrm{M} \mathrm{NaOH}$ [39].

After $72 \mathrm{~h}$, medium-cultured colonies (aggregates of bacteria) were grown, and then counted to determine which plates were populated with 20-100 medium colonies, which had higher probability of being ureolytic bacteria. Using a sterilized toothpick, each colony from the selected medium was moved into its own medium for the next step, which was to select urease bacteria using a cresol red solution. Urease activity measured in a $10 \mathrm{~mL}$ solution was put into a polystyrene screw bottle. Furthermore, transfer a certain amount of bacteria in solid medium using sterilized toothpick, then taken and added to a polystyrene screw bottle containing the urease activity measurement solution. The total potential urease bacteria found is less than $5 \%$ as the percentage ratio of ureolytic bacteria among the 527 colonies from the total number isolated from the rock samples. The diversity of microbes known in beachrock encompass three recognized ureolytic bacterial groups, most of which species are assorted microbial eukaryotes. The most frequently isolated $16 \mathrm{~S}$ rDNA gene sequences include those from acid bacteria, Actinobacteria, and Chloroflexi [40-42]. The results of a homology search in the GenBank/DDBJ/EMBL, three group of bacteria that were highly homologous to the 16S rDNA nucleotide sequence of the species whereas Oceanobacillus profundus (CIP109535-HQ595230), Vibrio Maritimus (R40493-GU929925), and Pseudoalteromonas tetradonis (KMM458-AF214729). The strains in the 16S DNA gene sequences are shown in Figure 4 . The $O$. profundus is a gram-positive species that are motile, aerobic, rod-shaped $(0.2-0.4 \mu \mathrm{m})$ and classified as biosafety level 1 bacteria. The others, $V$. maritimus and P. tetradonis are gram-negative. The former are motile bacilli $1 \mu \mathrm{m}$ wide and $1.5-4.0 \mu \mathrm{m}$, whereas the latter are strictly aerobic, motile with one polar flagellum, form either straight rods (or rod-shapes), $0.5-0.8 \times 1.0-1.5 \mu \mathrm{m}$ when in exponential growth phase. Even though $V$. maritimus and P. tetradonis are classified as biosafety level 1, but further analysis of Vibrio maritimus caused it to be eliminated because of similarity to Vibrio cholerae (i.e., V. cholerae). 


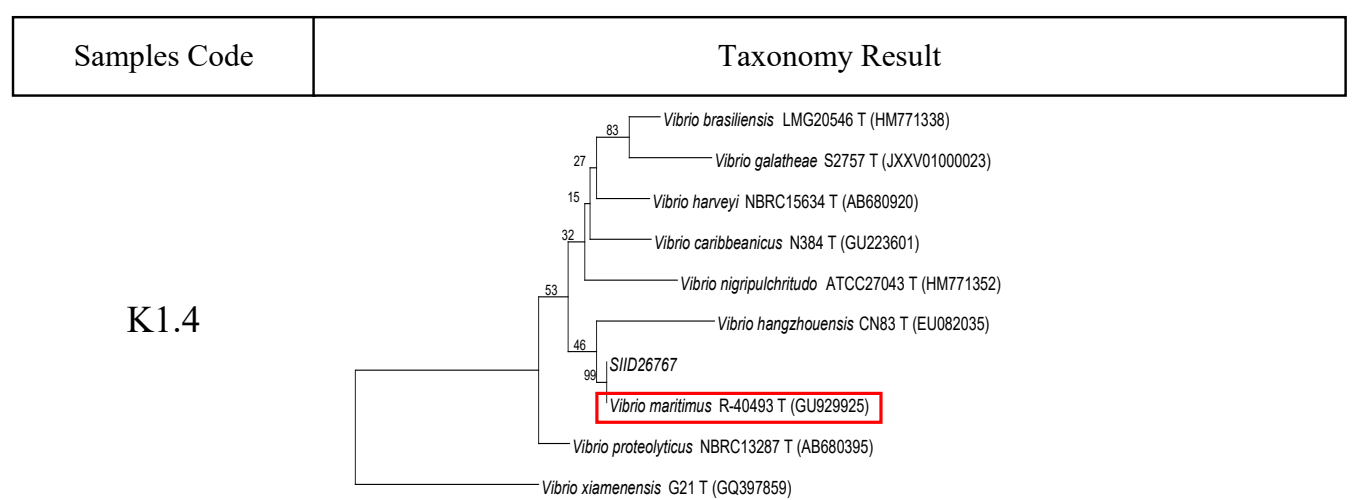

P1.7

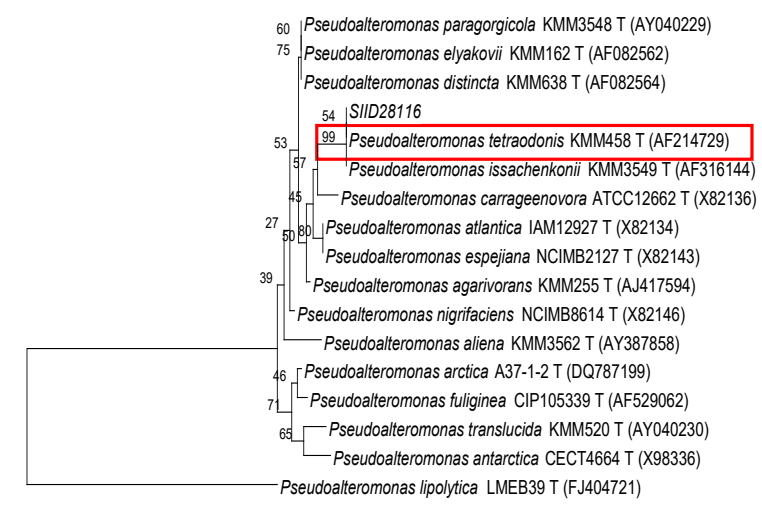

P1.18

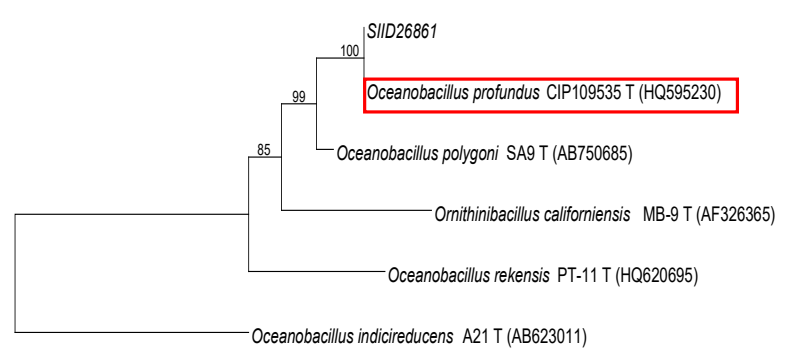

Figure 4. Phylogenetic trees result of $16 \mathrm{~S}$ rDNA nucleotide sequence of local bacteria taxonomy (red-frame).

\subsubsection{Microbial Population Count and Urease Activity Test}

The time course of cell growth and urease activity over $15 \mathrm{~d}$ are shown in Figure S8. The cell concentration increased for $2 \mathrm{~d}$ and then reached the stationary phase. The urease activity of the cell culture increased with cell growth. Based on this result, the production of urease would be a growth-associated system. Considering microbial-based sand solidification, which should be sustained for relatively long duration for adequate solidification, the long-term stability of the enzyme would be advantageous in the MICP process [36]. As shown in Figure S8 (Supplementary Material), the urease activity of $P$. tetradonis is higher than that of $O$. profundus and $V$. maritimus. The bacteria expressed the highest urease activity after $48 \mathrm{~h}$ incubation, with only appreciable levels at 24 and $72 \mathrm{~h}$. Even though the bacterial strains are considered biosafety level one (safe for the human body and environment), but some strains of $V$. maritimus are pathogenic $[40,41]$ therefore for further research, only O. profundus and $P$. tetradonis were used to continue the deep research to develop the MICP method. The tetradonis were used to continue the deep research to develop the MICP method. The test tube precipitation test results are a good relative indication test tube precipitation test results are a good relative indication of the potential of each strain for sand solidification by MICP [42-44]. This is because the improvement 
in strength is proportional to the amount of bio-precipitate formed. Same calcium chloride solution mixed with urease $[0.5 \mathrm{M}]$ then dissolved into $7 \mathrm{~mL}$ distilled water with urease, calcium chloride and bacteria composition in the ratio of 1:1:1 whereas $10 \mathrm{~mL}$ in total, hence the control tube is without bacteria $[45,46]$. The results indicate that the strain of $P$. tetradonis shows the highest performance for microbial induced carbonate precipitation and the weight of precipitate is approximately two times more than the others (Figure 5).

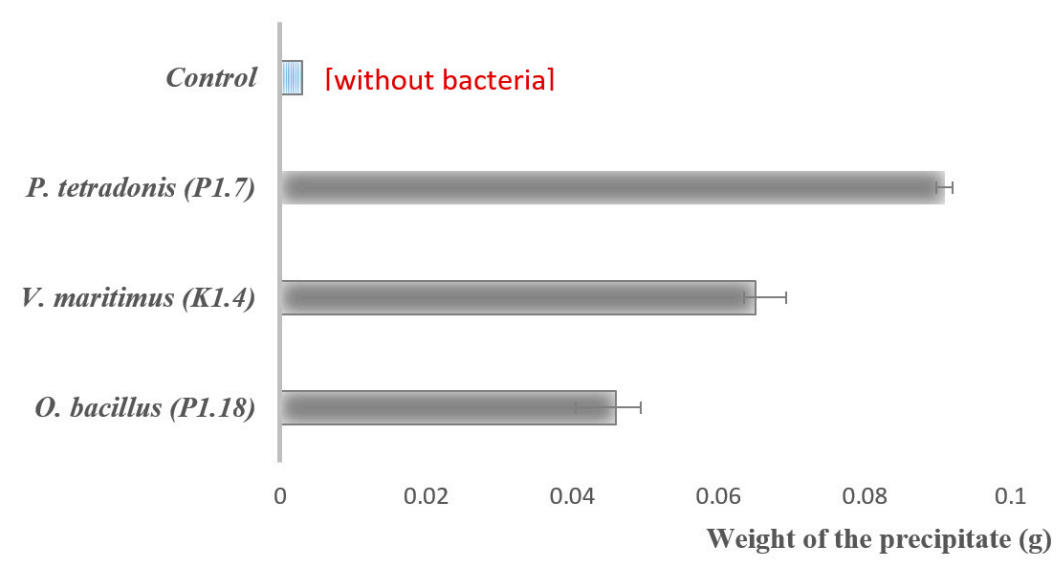

Figure 5. Microbial induced carbonate precipitation capacity of isolated strains.

In the MICP biocementation technique, urease enzyme activity is the key bioindicator of whether the artificial beachrock process is successful or not. The effect of different temperature conditions is shown in Figure 6 a for both species. High activity was obtained in the range $10-80{ }^{\circ} \mathrm{C}$, but the maximum urease activity was obtained at $\sim 40{ }^{\circ} \mathrm{C}$ in this study. Most of urease molecules are known to be composed of protein subunits and the subunits of this urease bind strongly to each other. This leads to high stability of the urease during long-term cultivation $[39,42,44]$. Urease activity under different $\mathrm{pH}$ conditions is shown in Figure 6b. The results show maximum activity at $\mathrm{pH}$ 2.0-12.0. Considering these ranges of temperature and $\mathrm{pH}$, the results were different from those of Fujita et al. [39]. In that work, it is mentioned that the results for maximum temperature show an exponential increase toward the environment temperature of the buffer solution, and the method for measurement of urease activity involved the use of an ammonia meter with Tris/ $\mathrm{HCl}$ buffer solution. Meanwhile, in this research, to measure urease activity, we used ethylene diamine tetra acetic acid (EDTA)buffer solution for the indophenol blue method then detected changes of optical density $(630 \mathrm{~nm})$ with a colorimeter. The results of Fujita et al. [39] and this research are quite different except for the patterns of bacterial growth and urease activity. All bacteria strain activities were carried out three times to minimize the measurement error factor.
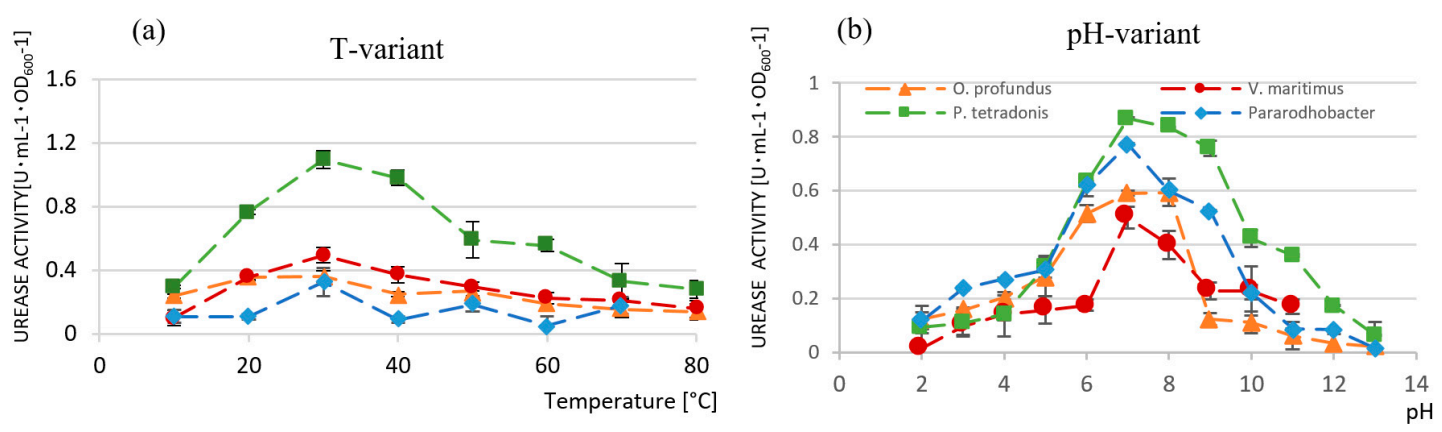

Figure 6. (a) Effect of reaction temperature on urease activity of the whole cell at $\mathrm{pH} 7(1 \mathrm{mM}$ EDTA-disodium salt solution); (b) Effect of reaction $\mathrm{pH}$ on urease activity of the whole cell at $37^{\circ} \mathrm{C}$ $1 \mathrm{mM}$ EDTA-disodium salt solution. 


\subsection{Indigenous Ureolytic Bacteria Ability for Beach Sand Solidification by MICP Treatment}

The reactant and the bacterial cell concentration are two primary factors that govern the degree and the homogeneity of the strength increment over the treatment depth. The experimental scheme were shown in Figure S4, using both sand sample from local Yogyakarta south coast. The local strength of the sand specimens underwent different treatment conditions with respect to the aforementioned two parameters, which are illustrated in Figure 7. However, the cementation reagent contained equimolar concentrations of urea and $\mathrm{CaCl}_{2}$ as in $\mathrm{Ng}$ et al. [47]. When two samples injected with $0.5 \mathrm{M}$ cementation solution were considered, it was clear that the specimen with bacteria injected twice showed significantly greater strength than that of the specimen injected with bacteria only once (at the beginning). According to previous records, it was deduced that higher concentrations of bacteria populations enhance the amount of $\mathrm{CaCO}_{3}$ precipitate and, thus, the results of MICP treatment [48]. Generally, bacteria play two key roles in the biocementation process: (i) catalysis of urea hydrolysis and (ii) provision of nucleation sites [49]. The initial investigations on urease activity of the isolated strain showed that enzymatic activity diminishes over time. Moreover, there are several other factors that could gradually inhibit the bacteria from performing their intended role as a catalyst for urea hydrolysis over the entire treatment time period. All the samples were strongly cemented and the estimated average (as well as individual) unconfined compressive strength (UCS) test values from two independent tests for all the cases were above $3 \mathrm{MPa}$.

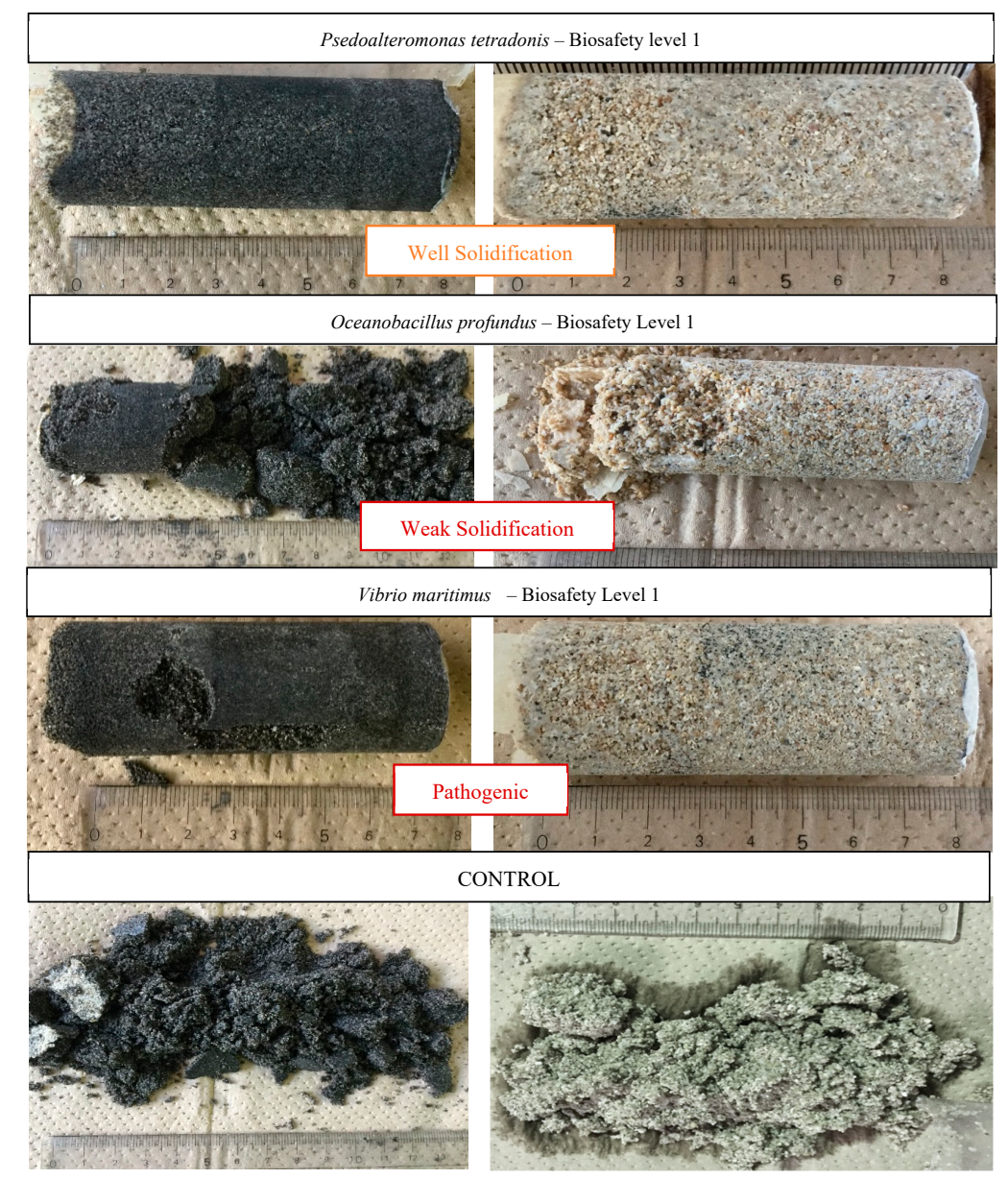

Figure 7. Beach sand treatment test using microbial induced carbonate precipitation after 14 days treatment. Sample with nigrescent color (left) is Quartz silica sand from Parangtritis beach and sample with whitish color (right) is carbonate coarse sand from Krakal-Sadranan beach sand. 


\section{Discussion}

Beachrock is generally cemented in the tidal zone with a large amount of aragonite, high-magnesium calcite (HMC), and low-magnesium calcite (LMC). Carbonate cementation in the marine environment forms acicular-radial and spacious types of cement texture, whereas the tidal zone cement is indicated by aragonite or HMC. Meniscus bridge cement indicate LMC composition $[1,6,46,48]$. Beachrock found in Indonesia consisted of calcium, magnesium, sodium, and phosphorus element. However, according to the ICP-AES data, the composition is not similar to those of limestones and/or other beachrock which typically consists of silica and carbonate [34,35]. Hence, some previous studies have suggested that bacterial metabolism is related to the precipitation of rocks $[42,49]$ and that the end products lower the thermodynamic boundary for cement nucleation and increases the rates of the physicochemical processes involved [42]. A technique for bio-cementation using microbial induced carbonate precipitation (MICP) for calcium carbonate precipitation could be biologically controlled or induced. Bacteria serve as a catalyst in urea hydrolysis through the generation of urease enzyme to form calcium carbonate cement $[46,50]$. Specific cement types are recognized as (i) acicular, fibrous, and bladed fabrics; (ii) radial fibrous and fascicular-optic fabrics; (iii) micro-and cryptocrystalline fabrics; (iv) equant spar, syntaxial overgrowth fabrics, scalenohedral calcites, and peloidal fabrics; and (v) non-carbonates. These types indicate incipient early marine cementation leading to a reduction in pore-space in near-seafloor sediments [51]. Krakal-Sadranan Beaches happen to follow the same pattern, in which the meniscus cement solution is characterized by domination by crystalline aragonite and magnesium-calcite, which are soluble in water.

A summary of the mineralogy and geochemical characteristics of the various beachrock samples from the study area, along with interpretation of the beachrock depositional environment and the sources of trace elements, are depicted in Table 4. The multistage mineralization products of the biota are also known as microbialites from marine activity. For example, successive stages of biocementation have been described for Pararodhobacter sp. and Oceanobacillus profundus, whereas ureolytic bacteria precipitate aragonite nanograins outside their cell walls and, later, the cell content is replaced by aragonite. The aragonite crystals that formed outside and inside the cell wall are different in shape and size $[44,52]$. In the case of mineralized varieties, superficial crusts preserve, as well as complicate, the morphology of the organisms, whereas biomineralized fabrics within skeletal, molluscan, and some thrombolites probably retain clearer details. In this environment, interference of the organic process by algae and microbial activities may accelerate the process $[32,53,54]$. The extent of vadose and freshwater diagenetic features indicates that more ancient beachrock had occupied inland positions for a relatively long time. Commonly, precipitation is induced by micro-organisms, mostly ureolytic bacteria, and cyanobacteria. Micrite is a major, often dominant component of these deposits [55-57]. For the deposits themselves, the term "microbialite" is widely used. The drawback is that the word has a strong genetic connotation. It stands for autochthonous micrite as opposed to allochthonous micrite that was transported and deposited as fine-grained sediment [58]. Beachrock in tropical areas mostly generate from microbial controlled of carbonate precipitation, which is controlled by the sunlight, temperature, latitudinal zonation of skeletal production, nutrient, and salinity [57]. This is proven from the interpretation of geochemical ICP data (Table 4) which is salinity in the oxidative condition is controlled the sedimentary process, and also microbial activity such as algae (for photosynthesis), cyanobacteria, and ureolytic bacteria were found inside the beachrock. The environment controls of carbonate precipitation an important factor of beachrock consisted whereas chemical requirement is supply of alkalinity in the form of the anions $\mathrm{HCO}^{-3}$ and $\mathrm{CO}_{2}{ }^{-3}$. 
Table 4. Summary of deposition process affecting the limestone sand and beachrock at Krakal-Sadranan, Yogyakarta, Indonesia.

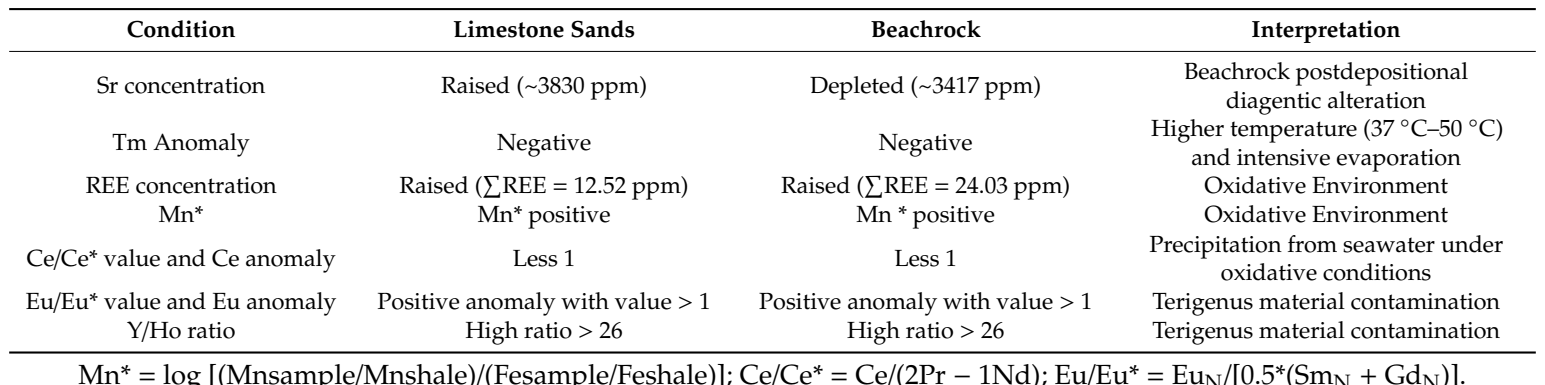

\section{Conclusions}

Isolated strains of native bacteria belonging to Psedoalteromonas tetradonis, Oceanobacillus profundus, and Vibrio maritimus were identified and cultured. These are moderately alkalo-tolerant bacteria, showing maximum growth and urease activity at an ambient temperature of $37^{\circ} \mathrm{C}$, which is compatible with the tropical climate prevailing in the target region. Microbial carbonate overriding environmental control is seen in the present day by localization of microbial carbonates in calcareous streams and springs and in shallow tropical seas, and in the past by temporal variation in the abundance of marine microbial carbonates. Only $\sim 4.7 \%$ of ureolytic bacteria and algae precipitation, respectively, were assumed to be catalytic factors in beachrock precipitation. The beachrock of Krakal-Sadranan beach in the studied area can be categorized into non-beachrock, unconsolidated beachrock (similar to limestone sands), and well-consolidated beachrock consisting of mostly rock-mineral. Beachrock has a fairly consolidated feature and consists of a mixture of gravel-sized deposits of sand in the form of limestone fragments, calcite, and fossil minerals, and almost $50 \% \mathrm{CaO}$ content (carbonaceous). The interpretation of the cesium anomaly can be used to determine the source of the REEs in this formation, indicating that the beachrock deposition processes originated from the precipitation of seawater under oxidative conditions. This can be interpreted as the beachrock derived from microbial process involving terrigenous materials under oxidative conditions. Thus, the most favorable condition is to have the presence of oxygenated material contamination. Beachrock occurrence in an area depends on highly geological factors that contribute the matrix interior. Indonesian geological settings seem to be dominated by marine activities of the Pacific Ocean and may be labeled as oxidative conditions.

Supplementary Materials: The following are available online at http://www.mdpi.com/2076-3417/10/2/520/s1, S1-S3 Regional geology of research study; Figure S1. Beachrock occurrences in Krakal-Sadranan, Yogyakarta, Indonesia; Figure S2: Geological settling of Yogyakarta south coast, Indonesia. (a) Krakal-Sadranan beach consists of limestone formation between Wonosari formation interfingering with Punung formation (b) Parangtritis beach consist of alluvial Merapi volcano deposit.; Figure S3: Map of the esearch area; Figure S4: Syringe cementation test scheme; Figure S5: Stratigraphic of the Trench CD: (A) Petrographic on cross polarized nicol (XPL, A1) and plane polarized nicol (PPL, A2) with $\mathrm{sf}=$ skeletal fragment; $\mathrm{mc}=$ micrite; $\mathrm{sp}=$ sparite; $\mathrm{ca}=$ calcite, ar = aragonite. (B) Degree of cementation based on composition of beachrock; Figure S6: Stratigraphic of the Trench EF: (A) Petrographic on cross polarized nicol (XPL, A1) and plane polarized nicol (PPL, A2) with sf = skeletal fragment; $\mathrm{mc}=$ micrite; $\mathrm{sp}=$ sparite; $\mathrm{ca}=$ calcite, $\mathrm{ar}=$ aragonite. $(\mathrm{B})$ Degree of cementation based on composition of beachrock; Figure S7: Beachrock elements analysis based on (a) PAAS (Post-Archean Australian Shale from Guimaraes et al. [20]) normalized major oxide diagram for limestone samples of beachrock, (b) Trace element normalizing based on Average Phaenerozoic Limestone from Condie et al. [19]; Figure S8: Cell growth and urase activity of (a) Pseudoalteromonas tetradonis, (b) Oceanobacillus profundus, and (c) Vibrio maritimus; Table S1: Standart normalization rare earth element (REE) results concentration for sediment. The major element of beachrock (ppm), trace element result (in ppm), and REE of beachrock (in ppm).

Author Contributions: L.R.D., and S.K. performed the measurements, S.K., K.N., and L.R.D. were involved in planning and supervised the work, L.R.D., processed the experimental data, performed the analysis, drafted the manuscript and designed the figures. L.R.D., A.D.T., and D.H.B., manufactured the samples and characterized them with thin section analysis include column stratigraphy, L.R.D., aided in interpreting the results and worked on the manuscript, S.K., K.N., and L.R.D., designed and planning the work. All authors discussed the results and commented on the manuscript. All authors have read and agreed to the published version of the manuscript. 
Funding: This research received no external funding.

Acknowledgments: The authors deeply appreciate Muhammad Hidayat, M. Zharfan Bimantoro, Reny Rafiqah, Dobrak Tirani, Jum Satriani, Fathia Lutfiananda, and Enggar Suwandi as field geology and geophysics exploration of UGM Indonesia for their constant assistance with the experiments; Doni Eka Prakasa who permitted access to the Get-In CICERO Laboratory that was supported by BMBF, Dept. of Geological Engineering, UGM; Imam Suyanto as author's supervisor in geophysical measurement, Arief Rahmadi as author's partner in field acquisition and deeply honor to Embassy of the Republic of Indonesia in Tokyo regarding the permit letter number B-00446/TOKYO/181227.

Conflicts of Interest: The authors declare no conflict of interest.

\section{References}

1. Vousdoukas, M.I.; Velegrakis, A.F.; Plomaritis, T.A. Beachrock occurrence, characteristics, formation mechanisms and impacts. Earth Sci. Rev. 2007, 85, 23-46. [CrossRef]

2. Russell, R.J.; McIntire, W.G. Beach cusps. Geol. Soc. Am. Bull. 1965, 76, 307-320. [CrossRef]

3. Woodroffe, C.D.; Stoddart, D.R.; Spencer, T.; Scoffin, T.P.; Tudhope, A.W. Holocene emergence in the Cook Islands, South Pacific. Coral Reefs 1990, 9, 31-39. [CrossRef]

4. Pirazzoli, P.A.; Costa, S.; Dornbusch, U. Flood threat anomaly for the low coastal areas of the English Channel based on analysis of recent characteristic flood occurrences. Ocean Dyn. 2007, 57, 501-510. [CrossRef]

5. McLean, R. Beach Rockin the Encyclopedia of Modern Coral Reefs: Structure, Form and Process; Springer: Dordrecht, The Netherland, 2011; p. 1236.

6. Avcioğlu, M.; Yiğitbaş, E.; Erginal, A.E. Beachrock formation on the coast of Gökçeada Island and its relation to the active tectonics of the region, northern Aegean Sea, Turkey. Quat. Int. 2016, 401, 141-152. [CrossRef]

7. Ginsburg, R.N. Beachrock in south Florida. J. Sediment. Res. 1953, 23, 85-92. [CrossRef]

8. Kelletat, D. Beachrock as sea-level indicator? Remarks from a geomorphological point of view. J. Coast. Res. 2006, 22, 1558-1564. [CrossRef]

9. Moore, W.S. The subterranean estuary: A reaction zone of ground water and sea water. Mar. Chem. 1999, 65, 111-125. [CrossRef]

10. Neumeier, U. Le Rôle de L'activité Microbienne dans la Cimentation Précoce des Beachrock (Sédiments Intertidaux) - The Role of Microbial Activity in Early Cementation of Beachrock. Ph.D. Thesis, University of Geneva, Geneva, Switzerland, 1998.

11. Zhu, X.; Linham, M.M.; Nicholls, R.J. Technologies for Climate Change Adaptation-Coastal Erosion and Flooding; TNA Guidebook Series; Danmarks Tekniske Universitet, Risø Nationallaboratoriet for Bæredygtig Energi: Roskilde, Denmark; University of Southampton: Southampton, UK, 2010; p. 167.

12. Jones, A.; Phillips, M. Disappearing Destinations: Climate Change and the Future Challenges for Coastal Tourism; Cabi: London, UK, 2011; p. 296.

13. Pilkey, O.H.; Cooper, A. The Last Beach; Duke University Press: Durham, UK, 2014; p. 256.

14. Barragan, J.M.; Andreis, M. Analysis and trends of the world's coastal cities and agglomerations. Ocean Coast Manag. 2015, 114, 11-20. [CrossRef]

15. Shi, P.; Kasperson, R. World Atlas of Natural Disaster Risk; Springer: Berlin/Heidelberg, Germany, 2015 ; p. 368. [CrossRef]

16. Van Bemmelen, R.W. General Geology of Indonesia and Adjacent Archipelagoes; Government Printing House: The Hague, The Netherlands, 1949; p. 732.

17. Surono, B.T.; Sudarno, I. Geological Map of the Surakarta-Giritontro Quadrangles, Jawa, 1408-3 and 1407-6 Quadrangles, Scale 1:100.000; Research Center and Geology Development, Department of Mining and Energy: Jakarta, Indonesia, 1992.

18. Toha, B.; Purtyasti, R.D.; Srijono Soetoto Rahardjo, W.; Pramumijoyo, S. Geology of Southern Mountain Area: A Contribution (in Indonesian). In Geology and Geotechnic Java Island, Since Late Mesozoic to Quarternary; Indonesian Journal ON Geoscience: Jakarta, Indonesia, 1994; pp. 19-36.

19. Sudarno, I. Tectonic Control toward Structure Occurrences in Paleogene and Neogene Rock of Java Southern Mountain, Yogyakarta, Indonesia. Master's Thesis, Bandung Institute of Technology, Bandung, Indonesia, 1997.

20. Verstappen, H.T. Outline of the Geomorphology of Indonesia; ITC Enschede: Enschede, The Netherlands, 2000; Volume 79, p. 212.

21. Nichols, G. Sedimentology and Stratigraphy; John Wiley \& Sons: West Sussex, UK, 2009; p. 420. 
22. Martin, T.D.; Brockhoff, J.T.; Creed, J.T. Method 200.7 Determination of Metals and Trace Elements in Water and Wastes by Inductively Coupled Plasmaeatomic Emission Spectrometry Revision 4.4 EMMC Version, 200.7 e1, 58 ; U. S. EPA: Washington, DC, USA, 1994.

23. Condie, K.C.; Wilks, M.; Rosen, D.M.; Zlobin, V.L. Geochemistry of metasediments from the Precambrian Hapschan series, eastern Anabar Shield, Siberia. Precambrian Res. 1991, 50, 37-47. [CrossRef]

24. Guimaraes, J.T.F.; Cohen, M.C.L.; Franca, M.C.; Silva, A.K.T.D.; Rodrigues, S.F.S. Mineralogical and Geochemical Influences on Sediment Color from Amazon Wetlands Analyzed by Visible Spectrophotometry. Acta Amaz. 2013, 43, 331-342. [CrossRef]

25. Rollinson, H.R. Using Geochemical Data: Evaluation, Presentation, Interpretation; Routledge: London, UK, $2014 ;$ p. 73.

26. Folk, R.L. Spectral Subdivision of Limestone Types. In Classification of Carbonate Rocks; Ham, W.E., Ed.; American Association of Petroleum Geologists: Tulsa, OK, USA, 1962; pp. 62-84. [CrossRef]

27. Pratama, W.; Dewi, S.C.; Sari, I.Z.R.; Hardiyati, A.; Wajong, A.E. Distribution and Abundance of Macroalgae in Intertidal Zone of Drini Beach, Gunung Kidul, DIY. KnE Life Sci. 2015, 2, 514-515. [CrossRef]

28. Romimohtarto, K.; Juwana, S. Biologi Laut: Ilmu Pengetahuan Tentang Biota Laut; Djambatan: Jakarta, Indonesia, 2009.

29. Trono, G.C., Jr. Seaweed. In The Living Marine Resources of the Western Central Pacific. Volume 1. Seaweed, Corals, Bivalves, and Gastropods; Carpenter, K.E., Niem, V.H., Eds.; Food and Agriculture Organization of the United Nations: Rome, Italy, 1998; pp. 19-96.

30. Baldrian, P. The known and the unknown in soil microbial ecology. FEMS Microbiol. Ecol. 2019, 95. [CrossRef] [PubMed]

31. Karkani, A.; Evelpidou, N.; Maroukian, H.; Kawasaki, S. Study of Beachrock in East Attica. Bull. Geol. Soc. Greece 2016, 50, 434-440. [CrossRef]

32. Porta, G.D. Carbonate Build-Ups in Lacustrine, Hydrothermal and Fluvial Settings: Comparing Depositional Geometry, Fabric Types and Geochemical Signature; Special Publication; Geological Society: London, UK, 2015; Volume 418, pp. 17-68. [CrossRef]

33. Alshuaibi, A.A.; Khalaf, F.I.; Al-Zamel, A. Calcareous thrombolitic crust on Late Quaternary beachrock in Kuwait, Arabian Gulf. Arab. J. Geosci. 2015, 8, 9721-9732. [CrossRef]

34. Atmoko, D.D.; Titisari, A.D.; Idrus, A. Geochemical Characteristics of Limestone of Wonosari-Punung Formation, Gunungkidul Regency, Yogyakarta, Indonesia. Indones. J. Geosci. 2018, 5, 179-197. [CrossRef]

35. Bolhar, R.; Kamber, B.S.; Moorbath, S.; Fedo, C.M.; Whitehouse, M.J. Characterisation of Early Archaean Chemical Sediments by Trace Element Signatures. Earth Planet. Sci. Lett. 2004, 222, 43-60. [CrossRef]

36. Janetzki, N.; Fairweather, P.G.; Benkendorff, K. Inventory of Rock Types, Habitats, and Biodiversity on Rocky Seashores in South Australia's Two South-East Marine Parks: Pilot Study; A Report to the South Australian Department of Environment, Water, and Natural Resources; Flinders University: Adelaide, Australia, 2015; p. 61.

37. Mauz, B.; Vacchi, M.; Green, A.; Hoffmann, G.; Cooper, A. Beachrock: A tool for reconstructing relative sea level in the far-field. Mar. Geol. 2015, 362,1-16. [CrossRef]

38. Tostevin, R.; Shields, G.A.; Tarbuck, G.M. Effective Use of Cerium Anomalies as a Redox Proxy in Carbonate-dominated Marine Settings. Chem. Geol. 2016, 438, 146-162. [CrossRef]

39. Fujita, M.; Nakashima, K.; Achal, V.; Kawasaki, S. Whole-cell Evaluation of Urease Activity of Pararhodobacter sp., Isolated from Peripheral Beachrock. Biochem. Eng. J. 2017, 124, 1-5. [CrossRef]

40. Oliver, J.D.; Pruzzo, C.; Vezzulli, L.; Kaper, J.B. Vibrio species. In Food Microbiology; American Society of Microbiology: Washington, DC, USA, 2013; pp. 401-439.

41. Elhadi, N.; Radu, S.; Chen, C.H.; Nishibuchi, M. Prevalence of potentially pathogenic Vibrio species in the seafood marketed in Malaysia. J. Food Prot. 2004, 67, 1469-1475. [CrossRef] [PubMed]

42. Danjo, T.; Kawasaki, S. Formation Mechanism of Beachrock in Okinawa and Ishikawa, Japan, with a Focus on Cements. Mater. Trans. 2014, 55, 493-500. [CrossRef]

43. Taylor, J.C.; Martin, H.C.; Lise, S.; Broxholme, J.; Cazier, J.B.; Rimmer, A.; Kanapin, A.; Lunter, G.; Fiddy, S.; Allan, C.; et al. Factors influencing success of clinical genome sequencing across a broad spectrum of disorders. Nat. Genet. 2015, 47, 717. [CrossRef]

44. Daryono, L.R.; Titisari, A.D.; Warmada, I.W.; Kawasaki, S. Comparative characteristics of cement materials in natural and artificial beachrock using a petrographic method. Bull. Eng. Geol. Environ. 2018, 78, 3943-3958. [CrossRef] 
45. Kandianis, M.T.; Fouke, B.W.; Johnson, R.W.; Veysey, J.; Inskeep, W.P. Microbial biomass: A catalyst for CaCO3 precipitation in advection-dominated transport regimes. Geol. Soc. Am. Bull. 2008, 120, 442-450. [CrossRef]

46. Van Paassen, L.A.; Pieron, M.; Mulder, A.; Van der Linden, T.J.M.; Van Loosdrecht, M.C.M.; Ngan-Tillard, D.J.M. Strength and deformation of biologically cemented sandstone. In Proceedings of the ISRM Regional Conference EUROCK, Cavtat, Croatia, 29-31 October 2009; pp. 405-410, ISBN 978-0-415-80481-3.

47. Ng, W.S.; Lee, L.M.; Khun, T.C.; Ling, H.S. Factors Affecting Improvement in Engineering Properties of. Residual Soil through Microbial-Induced Calcite Precipitation. J. Geotech. Geoenviron. Eng 2014. [CrossRef]

48. Okwadha, G.D.O.; Li, J. Optimum conditions for microbial carbonate precipitation. Chemosphere 2010, 81, 1143-1148. [CrossRef]

49. Zhu, T.; Dittrich, M. Carbonate Precipitation through Microbial Activities in Natural Environment, and Their Potential in Biotechnology: A Review. Front. Bioeng. Biotechnol. 2016, 4. [CrossRef]

50. Almajed, A.; Khodadadi Tirkolaei, H.; Kavazanjian, E., Jr. Baseline Investigation on Enzyme Induced Calcium Carbonate Precipitation. J. Geotech. Geoenviron. Eng. 2018, 144. [CrossRef]

51. Bathurst, R.G.C. Boring algae, micrite envelopes and lithification of molluscan biosparites. Geol. J. 1966, 5, 15-32. [CrossRef]

52. Mwandira, W.; Nakashima, K.; Kawasaki, S.; Ito, M.; Sato, T.; Igarashi, T.; Chirwa, M.; Banda, K.; Nyambe, I.; Nakayama, S.; et al. Solidification of sand by $\mathrm{Pb}$ (II)-tolerant bacteria for capping mine waste to control metallic dust: Case of the abandoned Kabwe Mine, Zambia. Chemosphere 2019, 228, 17-25. [CrossRef] [PubMed]

53. Marshall, J.; Barnhart, A.; Butcher, A.; Freimuth, C.; Khaw, F.; Lafromboise, E.; Landeros, M.; Morrish, S.; Olson, E.; Ritzinger, B.; et al. Beachrock horizons of the Nicoya Peninsula, Costa Rica: Geomorphology, petrology, and neotectonic significance. In Proceedings of the Coastal Sediments, San Diego, CA, USA, 11-15 May 2015. [CrossRef]

54. Arrieta, N.; Iturregui, A.; Martínez-Arkarazo, I.; Murelaga, X.; Baceta, J.I.; de Diego, A.; Olazabal, M.Á.; Madariaga, J.M. Characterization of ferruginous cements related with weathering of slag in a temperate anthropogenic beachrock. Sci. Total Environ. 2017, 581, 49-65. [CrossRef] [PubMed]

55. Wilson, J.L. Carbonate Facies in Geologic History; Springer: New York, NY, USA, 1975; p. 471.

56. James, N.P.; Bourque, P.A. Reefs and mounds. In Facies Models; Walker, R.G., James, N.P., Eds.; Geological Association of Canada: St. Johns, NL, Canada, 1992; pp. 323-345.

57. Schlager, W. Carbonate Sedimentology and Sequence Stratigraphy (No. 8); SEPM Society for Sedimentary Geology: Tulsa, OK, USA, 2005.

58. Wolf, K.H. Gradational sedimentary products of calcareous algae. Sedimentology 1965, 5, 1-37. [CrossRef] 